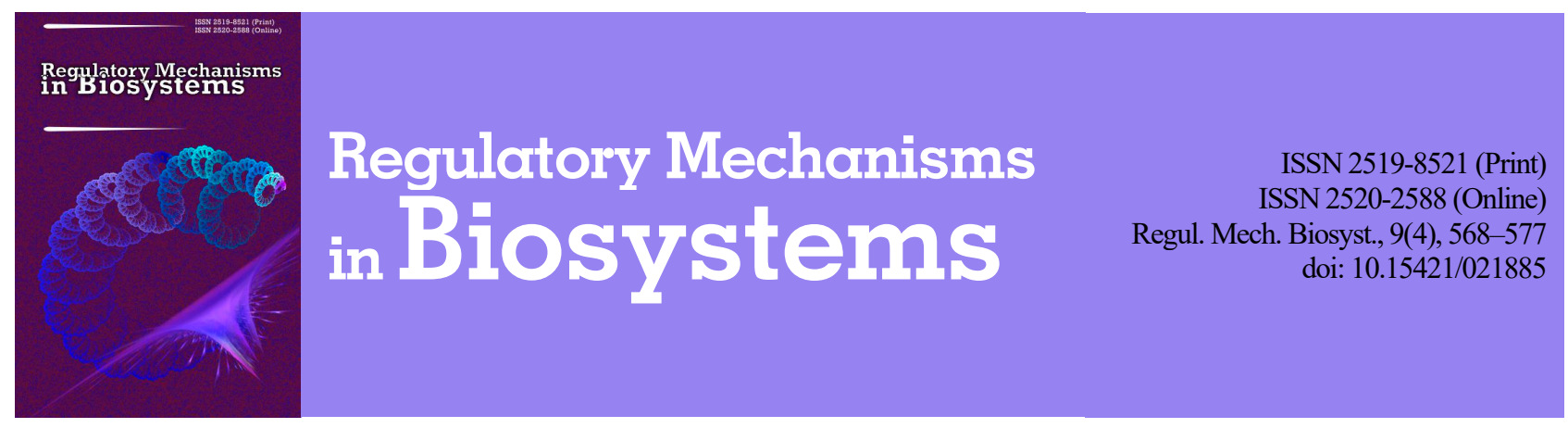

\title{
Population genetic structure of the Ukrainian black-pied dairy breed with the genome BoLA-DRB3
}

\author{
T. M. Suprovych*, T. M. Dyman**, M. P. Suprovych*, T. M. Karchevska*, T. V. Koval*, V. A. Kolodiy*** \\ *State Agrarian and Engineering University in Podilya, Kamianets-Podilskyi, Ukraine \\ **Bila Tserkva National Agrarian University, Bila Tserkva, Ukraine \\ ***Kamianets-Podilskyi National Ivan Ohienko University, Kamianets-Podilskyi, Ukraine
}

\section{Article info \\ Received 03.10.2018 \\ Received in revised form 20.10.2018 \\ Accepted 28.10.2018}

State Agrarian and Engineering

University in Podilya,

Shevchenko st., 13

Kamianets-Podilskyi,

32300, Ukraine

Tel.: +38-098-576-30-18.

E-mail:suprovycht@gmail.com

Bila Tserkva National Agrarian

University, pl. Soborna, 8/1,

Bila Tserkva, 09117, Ukraine.

Tel.: +38-067-975-73-46.

E-mail:

tetyanadyman@gmail.com

Kamianets-Podilskyi National Ivan Ohienko University, Ohienko st., 61, KamianetsPodilskyi, 32300, Ukraine

Tel.: +38-067-687-06-71.

E-mail: kolodiyva@ukr.net

Suprovych, T. M., Dyman, T. M., Suprovych, M. P., Karchevska, T. M., Koval, T. V., \& Kolodiy, V. A. (2018). Population genetic structure of the Ukrainian black-pied dairy breed with the genome BoLA-DRB3. Regulatory Mechanisms in Biosystems, 9(4), 568-577. doi:10.15421/021885

The second exon of the BoLA-DRB3 gene has the highest level of polymorphism among all studied loci of the major histocompatibility complex (MHC) in cattle, which allows it to be used for studying population-genetic structure and assessing the level of biodiversity of populations or comparing the biodiversity of particular herds. According to the results of typing the blood samples of 293 cows using the method of PCR-RLFP, we determined allele frequencies of the BoLA-DRB3 gene for the Ukrainian black-pied dairy breed. The study was conducted on three herds in Khmelnytskyi Oblast: LLC "Kozatska Dolyna 2006" (herd A, $\mathrm{n}=122$ ), agrofirm "Perlyna Podillya" (herd B, $\mathrm{n}=82$ ) and branch "Ridnyy kray" (herd C, $\mathrm{n}=89$ ). In total, 37 alleles were found: herd $\mathrm{A}-31$, herd $\mathrm{B}-25$ and herd $\mathrm{C}-28$. In total, in the three subpopulations seven alleles were found with frequency of over $5 \%$, the total share of which equaled $55.8 \%$. The most widely distributed allele was BoLA-DRB3.2*24, which composed $22.2 \%$ of the allele pool of the breed. We determined a high level of observed ( 0.89 to 0.95$)$ and expected $(0.93$ to 0.94$)$ heterozygosity. In herds A and B, there was determined domination of homozygotes. Deviation from HWE, calculated using the value of Wright's individual fixation index, equaled $\mathrm{F}_{\mathrm{IS}(\mathrm{A})}=0.016\left(\chi^{2}=0.03 ; \mathrm{P}>0.05\right)$ and $\mathrm{F}_{\mathrm{IS}(\mathrm{B})}=0.044\left(\chi^{2}=0.076 ; \mathrm{P}>0.05\right)$. In herd $\mathrm{C}$, we found excess of heterozygotes $\mathrm{F}_{\mathrm{IS}(\mathrm{C})}=-0.017\left(\chi^{2}=0.026 ; \mathrm{P}>0.05\right)$. Rather low values were determined for the subpopulation fixation index: $\mathrm{F}_{\mathrm{ST}(\mathrm{A})}=0.009\left(\chi^{2}=65.9 ; \mathrm{P}<0.01\right), \mathrm{F}_{\mathrm{ST}(\mathrm{B})}=0.012\left(\chi^{2}=47.2 ; \mathrm{P}<0.05\right)$ and $\mathrm{F}_{\mathrm{ST}(\mathrm{C})}=0.003\left(\chi^{2}=14.4\right.$; $\mathrm{P}>0.05)$, which were significantly different from the mean value for cattle $\left(\mathrm{F}_{\mathrm{ST}}=0.078\right)$, indicating insignificant reduction of heterozygosity and divergence between the subpopulations by the BoLA-DRB3 gene. To assess genetic diversity, we calculated parameters of effective allele number $\left(A_{e}\right)$ and Shannon's information index (I). In spite of the different numbers of alleles found in the selections, it was suggested that for assessing their diversity, an efficiency index will be used which shows the share of effective alleles among all alleles found in a subpopulation $\left(\mathrm{A}_{\mathrm{e}}\left(\mathrm{N}_{\mathrm{a}}\right)\right.$. The calculated values of the parameters equaled: herd $\mathrm{A}-\mathrm{A}_{\mathrm{e}}=$ 14.9, $\mathrm{A}_{\mathrm{e}} / \mathrm{N}_{\mathrm{a}}=0.48, \mathrm{I}=3.05$; herd $\mathrm{B}-\mathrm{A}_{\mathrm{e}}=14.5, \mathrm{~A}_{\mathrm{e}} \mathrm{N}_{\mathrm{a}}=0.58, \mathrm{I}=2.87$; herd $\mathrm{C}-\mathrm{A}_{\mathrm{e}}=16.4, \mathrm{~A}_{\mathrm{e}} \mathrm{N}_{\mathrm{a}}=0.59, \mathrm{I}=3.01$. Frequencies of BoLA-DRB3 alleles were used for calculating genetic similarity and standard genetic distances according to Nei. Cows of herds B and $\mathrm{C}$ were found to be more genetically affinitive by the BoLA-DRB3 gene. Standard genetic distance between them was the lowest $\mathrm{D}=0.13$, which coincides with the geographic locations and historical development of these populations. The results of the study prove that the studied herds have a high level of polymorphism. Frequency characteristics, values of expected heterozygosity, effective allele number, efficiency index and Shannon's information index compared to the similar parameters for Holstein, black-pied and some other local breeds of cattle indicate the high genetic diversity of the studied subpopulations of the Ukrainian black-pied dairy breed.

Keywords: biodiversity; alleles; PCR-RLFP; F-statistics; efficiency index; genetic distance; genetic similarity; cattle

\section{Introduction}

The modern "Synthetic theory of evolution" (STE) combines the fundamentals of Darwinism about the role of selection and the postulates of genetics, which make it possible to explain the impact of evolutionary factors within population systems. It reveals the mechanisms of the effect of the main evolutionary factors - mutations, genetic drifts, migration (flow of genes) and natural selection. Darwinists and geneticists began to speak the same language - the language of population genetics. STE initiated the intense development of statistical methods associated with the names of Galton, Pearson, Johannsen, Fisher, Chetverikov and many others (Gaevskij, 2002). The statistical approach allowed the removal of the contradictions between the laws of classical genetics of Mendel and inheritance of quantitative features. The successes of popu- lation genetics are especially notable in agriculture. The study of genetic structure of populations is a necessary component of selection work in cattle breeding.

Genetic-population peculiarities can manifest only in the groups of animals, which in general could be called populations. They are considered an elementary unit of evolution. The term "population" can have different definitions depending on the limiting factors (number, territory, environment, selection). From the perspective of population genetics it is a group of animals, within which the probability of a pair of members breeding together is many times higher than the probability of a member breeding together with a representative of other similar groups. In the study by Dobrzhansky (1970), a population is described as a reproductive group of organisms which have a similar gene pool or a group of individuals of a species which inhabit a certain part of their 
range over a long period of time partly or completely isolated from other similar groups of individuals of the same species. The meaning of the term "species" is much broader than "population" for the number of the living organisms of a species is higher than the number of a population, assuming that the location of a given population is not the only place of living and existence of the species it belongs to. Therefore, the term population usually refers to groups within a species or subspecies.

Populations are groups of more or less isolated subpopulations which can have different numbers, various systems of breeding, between which an exchange of genetic material can take place, and which are affected by different forms of selection (Kuznecov, 2014). The evolutionary form of subpopulation is often used in scientific articles (Nagylaki, 1998; Gómez-Castro et al., 2006; Kozyreva et al., 2014; Kovaljuk et al., 2015; Wang et al., 2015). In our opinion, a subpopulation is a group of animals inside a population or species, which interbreed, but are strictly limited in migration. Often this term is understood as a subdivision of a population which has special characteristics which belong to all its members. For example, limited territory of inhabitance (farm, region), distinctive feature (coat colour, polling, productive feature), peculiarities of selection, etc. Sometimes, instead of the term "subpopulation", the term "herd" is used (Oprzadek et al., 2012; Mosafer et al., 2012; Krajewska et al., 2015).

As an elementary unit of evolution in genetic studies of agricultural animals, the term "breed" is used. In FAO dictionary (Zaid et al., 2008), "breed" is determined as a group of domestic animals of a certain species, created under the effect of artificial selection, which is distinguished by the similarity of a number of morphological and physiological peculiarities and is affected by the same selection programme (with the same purposes and criteria of selection). Unlike the natural populations, breeds are not able to live without constant intervention of humans. This is a result of the work of humans with a certain number of animals. A breed forms and develops under the influence of particular socioeconomic factors in certain soil-climatic and farming conditions as a result of long term systematic and purposeful selection work (Gladiy et al., 2018). It is a complicated system of heterozygotic genotypes. Animals of a breed should be sufficiently numerous, have the same origin, pass on the breed features to the next generations (type, exterior, productivity).

From the perspective of population genetics, evolution is a change of frequency of alleles of the gene pool of a population taking place over generations (Stoltzfus, 2006). The genetic structure of a population is characterized by the qualitative composition of genes and certain frequencies of alleles and genotypes. The revealed peculiarities of their distribution form the basis of genetic-population analysis.

Currently, in the Bos taurus genome, 4,118 loci are mapped, over 3,100 variants of DNA-polymorphism are described. Over 800 variants of polymorphism were studied on 103 breeds of cattle (Sulimova, 2006). Analysis of polymorphism at the level of breed, population, herd or particular species can be used most efficiently with molecular-genetic markers (Deb et al., 2012) which are certain sequences of conservative areas of the genome. A genetic marker is polymorphism of DNA, which can easily be determined in molecular or phenotypical analysis. Most often, for molecular-genetic markers, there are selected intergenic spacers, coding or non-coding areas of the gene (Singh et al., 2014). These areas are characterized by a strict correlation between the changes of the genome and external parameters (Avise, 1994).

The marker systems of polymorphic nucleotide sequences of DNA allow genetic polymorphism to be tested directly at the level of genes. DNA-markers are universal and are more convenient to use than morphological, karyological or biochemical markers. This is related to the fact that the differences of individuals at a genetic level often do not manifest in postnatal ontogenesis due to the effect of domination or low level of expression. DNA-markers allow the problem to be solved of saturation of a genome with the markers and distinguishing practically any areas of DNA. For the analysis of genome, a large amount of different types of DNA-markers have been developed on the basis of single nucleotide polymorphisms (SNP) (Werner et al., 2004). They are inherited according to Mendel's laws, and are most often represented by a large number of alleles (several dozen), are indifferent to the impact of the environmental factors and they do not have pleiotropy for economically valuable features.

Molecular markers which reveal polymorphism at the level of DNA are the key markers in the sphere of animal genetics. Currently, for cattle, various genetic markers are suggested (Sulimova, 2004; Teneva \& Petrović, 2010; Singh et al., 2014). During the selection of a marker for population-genetic studies, one should take into account its informativity and individual level of complexity of typing, for such experiments are conducted on large selections of animals.

In this context, it seems convenient to use the gene BoLA-DRB3. It codes the antigens of the class II of the major histocompatibility complex of (MHC) of cattle. The gene is positioned in the Ila area of the sublocus of DR in the system BoLA and is composed of 6 exons. The second exon of the BoLA-DRB3 gene, which codes $\beta 1$-domen of the antigens of the class II, is highly polymorphic, which is necessary for bonding a broad range of alien antigens (Miyasaka et al., 2011; Behl et al., 2012).

Evolutionary processes of the MHC have formed a number of unique peculiarities of this gene. It is characterized by a clearly manifested natural polymorphism (Mosafer et al., 2012; Ranjbar et al., 2017). Using the method (www.ebi.ac.uk/ipd/mhc/group/BoLA) of sequence based typing (SBT), in the gene BoLA-DRB3 (Takeshima et al., 2002), 136 alleles were found. This is the highest indicator of polymorphism among all studied loci of the main complex of cattle histocompatability. Analysis of DRB polymorphism is also useful for determining the evolution history of MHC of Ruminantia. The low level of polymorphism in some Ruminantia animals, such as moose (Mikko \& Andersson, 1995a) and significant differences in the frequencies of alleles between the breeds of cattle in different continents (Mikko \& Andersson, 1995b; Peters et al., 2018) indicate that the selection, genetic drift and the effect of population bottleneck played an important role in forming alleles of classes I and II of MHC (Behl et al., 2012). Also, the BoLA-DRB3 gene is interesting as a universal (complex) marker related to the resistance to diseases, parameters of productivity and biological diversity of groups of cattle (Kulberg et al., 2007). The assessment of diversity with alleles of highly polymorphic genes can be compared to the assessment of about a dozen of two- or three-valent genes. Accordingly, using the results of analysis on only the BoLA-DRB3 gene is sufficient for assessing the level of biodiversity of populations in general or comparing the biodiversity of particular herds.

Polymorphism of exon 2 of the BoLA-DRB3 gene was studied in over 30 breeds of cattle. On the basis of the revealed alelle frequencies, there were determined the parameters of population-genetic structure of South African (Haikukutu et al., 2017), Mongolian, Yakut and Kalmyk (Ruzina et al., 2010), Argentinian Creole (Giovambattista et al., 2001), Chilean (Takeshima et al., 2015b), Indian (Das et al., 2012), Japanese (Takeshima et al., 2003; Miyasaka et al., 2012), Philippine native (Takeshima et al., 2014) and South American populations of cattle (Takeshima et al., 2015a).

Study of the biodiversity of the existing species of cattle and their genetic differentiation is one of the most important problems of the genetics of agricultural animals. The gene pool of dairy breeds is becoming depleted all around the world. The reason for this is intense selection for creating highly efficient dairy populations on the basis of a single breed - the Holstein breed. North America and Europe have become "victims" of Holsteinisation (Sulimova, 2006). Currently, this issue has reached Ukraine. At the same time, Ukrainian breeds of cattle are as broadly and systematically characterized as others according to molecular-genetic markers.

The multiform character of the BoLA-DRB3 gene, which developed evolutionally due to the need for variable structure of the cellular receptor in relation to alien protein antigens, has not only geographic, but natural variability, which is a reason for analyzing the peculiarities of its polymorphism both within a breed and in separate herds. In recent years, a number of studies have been conducted for revealing the polymorphism of the BoLA-DRB3 gene for Ukrainian cattle. The distribution of alleles was determined for black-pied and red-pied and grey dairy breeds (Suprovych \& Suprovych, 2013; Suprovych et al., 2017b). This research is continuing. The results we obtained for the allele polymor- 
phism of three herds of Ukrainian black-pied dairy breed and their comparison with the data of other researchers allowed us to conduct a substantial and integrated analysis of the genetic structure of the breed in terms of the BoLA-DRB3 genome.

\section{Materials and methods}

The research was carried out from 2014 to 2017 in three breeding farms in Khmelnitsky region: LLC "Kozatska Dolyna - 2006" (further the herd A), LLC scientific and production agrofirm "Perlyna Podillya" (herd B) and branch "Ridnyy Kray" (herd C), engaged in breeding the Ukrainian black-pied dairy breed. The locations of the farms in Khmelnitsky region are shown in Figure 1. Blood samples taken from 293 cows (herd A - 122, herd B - 82, herd C - 89 animals) were investigated in the Genetics Laboratory of the Institute of Animal Breeding and Genetics of the National Academy of Agrarian Science of Ukraine.

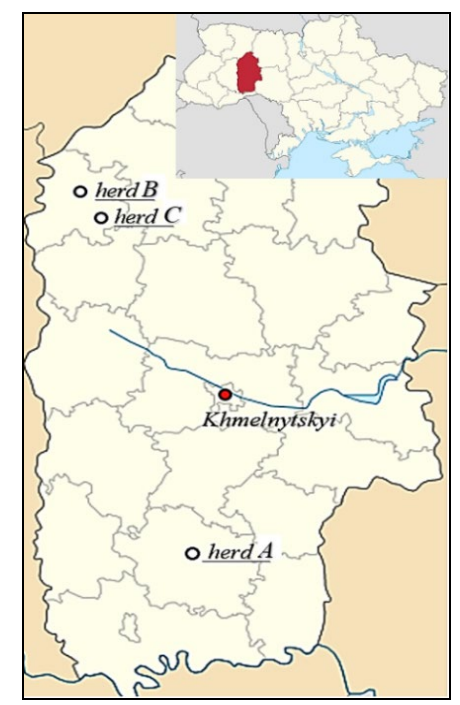

Fig. 1. Khmelnitsky region with locations of the studied herds

BoLA-DRB3 typing. The allele frequencies we detected based on the polymorphism analysis of the length of the restriction fragments PCR-RFLP of the products of amplification of the exon 2 of the BoLADRB3 gene (Van Eijk, 1992; Sulimova, 2004).

Isolation of DNA. DNA isolation from the blood was performed using "DIAtomTMDNA Prep200" kits (Isogen Laboratory Ltd.) in accordance with the manufacturer's instructions. DNA isolated from fresh biological material (yield was 5-10 $\mathrm{mg}$ from $200 \mathrm{ml}$ of whole blood) has high molecular weight (40-50 bp) and pure substance $\left(\mathrm{OD}_{260280 \mathrm{~nm}}=1.6-2.0\right)$. The concentration and purity of extracted DNA were assessed by spectrophotometery and electrophoresis in $1 \%$ agarose gel. With this purpose, 25,50 , and $100 \mathrm{ng}$ of $\lambda$ phage DNA and aliquots of solution with an unknown concentration were applied to agarose gel. Electrophoresis was performed in 1x Trisborate (TBE) buffer $(89 \mathrm{mM}$ Tris-OH, $89 \mathrm{mM} \mathrm{H}_{3} \mathrm{BO}_{3}, 2 \mathrm{mM}$ EDTA $)$ with $\mathrm{EtBr}(1 \mu \mathrm{g} / \mathrm{ml})$ added to the gel to stain DNA at constant voltage of $120 \mathrm{~V}$. The concentration of DNA of the test samples were determined by comparing the fluorescence intensity of the aliquots from solutions of unknown concentration and control $\lambda$ phage DNA.

Amplification. The BoLA-DRB3 exon 2 was amplifed by PCR using the single step PCR as modified from Van Eijk (Van Eijk et al., 1992). The PCR was carried out using ready-made sets of "GenPakR PCR Core", LLC "Izogen Laboratory", Russia. The total volume of mixture was $20 \mu \mathrm{l}$. The mixture contained $60 \mathrm{mM}$ Tris-HCL (pH 8.8), $2.5 \mathrm{mM} \mathrm{MgCl} 2,20 \mathrm{mM} \mathrm{KCl}, 15 \mathrm{mM}\left(\mathrm{NH}_{4}\right)_{2} \mathrm{SO}_{4}, 10 \mathrm{mM}$ mercaptoethanol, $0.1 \%$ Triton X-100, $0.2 \mathrm{mM}$ dNTP, 10 units of Klentaq DNA polymerase, $10 \mathrm{pM}$ of each primer, template DNA. Oligonucleotide primers for amplified of the exon 2 of BoLA-DRB3: HLO-30 (5'-3': TCCTCTCTCTGCAGCACATTTCC) and HLO-31 (5'-3': ATTCGC GCTCACCTCGCCGCT) for the first round of the reaction were used. DNA $(5 \mu \mathrm{l})$ was used as a template, regardless of its concentration.
Primers used for amplified second round: HLO-30 (5'-3': TCCTCTCT CTGCAGCACATTTCC) and HLO-32 (5'-3': TCGCCGCTGCACA GTGAAACTCTC). PCR products of the first round $(2 \mu \mathrm{l})$ were used for the second round. First stage was started from DNA denaturation at $95^{\circ} \mathrm{C}$ for $5 \mathrm{~min}$. followed by 10 cycles with denaturation $\left(94^{\circ} \mathrm{C}\right.$ for $1 \mathrm{~min}$.), annealing $\left(62.5^{\circ} \mathrm{C}\right.$ for $2 \mathrm{~min}$.) and elongation $\left(72^{\circ} \mathrm{C}\right.$ for $1 \mathrm{~min}$.) and a final extension at $72^{\circ} \mathrm{C}$ for $7 \mathrm{~min}$. Second stage was started initial denaturation $\left(95^{\circ} \mathrm{C}\right.$ for $5 \mathrm{~min}$.), was followed by 35 cycles of denaturation $\left(68^{\circ} \mathrm{C}\right.$ for $\left.30 \mathrm{~s}\right)$, and annealing-extension $\left(72^{\circ} \mathrm{C}\right.$ for $30 \mathrm{~s}$ ) and a final extension $\left(72^{\circ} \mathrm{C}\right.$ for $7 \mathrm{~min}$.). Contamination and selfpriming controls were included in each PCR round and $5 \mu \mathrm{L}$ of the last PCR product were electrophoresed on $1.5 \%$ agarose gels in order to check the quality and specificity of DNA fragment amplification.

RFLP Pattern. PCR products were digested separately with three restriction endonucleases: RsaI, HaeIII, XhoII (Promega, USA, New England BioLabs and SibEnzim, Russia). The restriction fragments we separated by electrophoresis in a $6 \%$ or $9 \%$ agarose gel. Amplification of exon 2 of the gene by means of a PCR followed by the analysis of restriction fragment length polymorphism and comparison of DNA patterns obtained using the three specified restriction endonucleases allows the identification of 54 alleles of the BoLA-DRB3 gene (Van Eijk et al., 1992; Gelhaus et al., 1995; Maillard et al., 1999).

Statistical analysis. The allele $\left(\mathrm{P}_{\mathrm{a}}\right)$ and genotype $\left(\mathrm{G}_{\mathrm{a}}\right)$ frequencies, observed heterozygosity $\left(\mathrm{H}_{\mathrm{o}}\right)$ we obtained by direct counting. Expected heterozygosity was determined through allele frequencies by the formula (Hedrick, 2010):

$$
H_{e}=1-\sum_{i=1}^{n} P_{a i}^{2}
$$

The normality of the distribution of frequencies of alleles was checked using Shapiro-Wilk statistic (SW) and Kolmogorov-Smirnov statistic with Lilliefors' significance (KS) in a standard set of IBM SPSS Statistics V24.0 (www.ibm.com/support/knowledgecenter/ru/SSLV MB_24.0.0/spss/product_landing.html).

Wright's F-statistics, or fixation indices characterized by individual $\left(\mathrm{F}_{\mathrm{IS}}\right)$, subpopulation $\left(\mathrm{F}_{\mathrm{ST}}\right)$ and population $\left(\mathrm{F}_{\mathrm{IT}}\right)$ levels of genetic structure of herds were determined according to observed, expected heterozygosity $\left(\mathrm{H}_{\mathrm{s}}\right)$ in the subpopulations with panmixia $\left(\mathrm{H}_{\mathrm{e}}\right)$ and expected heterozygosity in all population with panmixia using the following formulae (Kuznecov, 2014):

$$
\begin{aligned}
& \mathrm{F}_{\mathrm{IS}}=\left(\mathrm{H}_{\mathrm{e}}-\mathrm{H}_{\mathrm{o}}\right) / \mathrm{H}_{\mathrm{e}}, \\
& \mathrm{F}_{\mathrm{ST}}=\left(\mathrm{H}_{\mathrm{s}}-\mathrm{H}_{\mathrm{e}}\right) / \mathrm{H}_{\mathrm{s}}, \\
& \mathrm{F}_{\mathrm{IT}}=\left(\mathrm{H}_{\mathrm{s}}-\mathrm{H}_{\mathrm{o}}\right) / \mathrm{H}_{\mathrm{s} .}
\end{aligned}
$$

Pearson's $\chi^{2}$ test for $\mathrm{F}_{\mathrm{IS}}$ was calculated using the formula (Hedrick, 2010):

$$
\chi^{2}=\mathrm{NF}_{\mathrm{IS}}^{2} \text {, at } \mathrm{dF}=1 \text {, }
$$

and for $\mathrm{F}_{\mathrm{ST}}$ - using the formula (Workman \& Niswander, 1970):

$$
\chi^{2}=2 \mathrm{NF}_{\mathrm{ST}}\left(\mathrm{N}_{\mathrm{a}}-1\right) \text { at } \mathrm{dF}=\mathrm{N}_{\mathrm{a}}-1
$$

During the calculations, we took into account that the system is unilocus, and $\mathrm{N}-$ is the number of animals in the herd.

During the analysis, we determined the efficient number of alleles $A_{e}=1 /\left(1-H_{e}\right)$ and index of efficiency of $A_{e} / N_{a}$, which demonstrates the part of efficient alleles among all alleles found in the subpopulation $\left(\mathrm{N}_{\mathrm{a}}\right)$.

Determination of allele diversity was made on the basis of Shannon's information index (Begon et al., 2006):

$$
I=-\sum_{i=1}^{n}\left(P_{a i} \times \ln P_{a i}\right)
$$

For determining the phylogenetic relations between the studied herds, we determined genetic similarity and genetic distances (Nei \& Chesser, 1983).

Statistical analysis of the data was conducted in a standard set Microsoft Excel 2013 with our own programmers and integrated superstructures: GenAlEx 6.503 (http://biology-assets.anu.edu.au/GenAlEx/ Download.html) for calculating the Wright's statistics and StatistiXL 2.0 (www.statistixl.com) for cluster analysis with development of dendrograms.

\section{Results}

Comparison of the restriction patterns of 293 samples obtained with use of three endonucleases made it possible to identify 37 alleles of gene 
DRB3 (Table 1). Number of alleles found for herd A -31 , herd B -25 and herd $\mathrm{C}-28$.

Table 1

BoLA-DRB3.2* alleles frequencies of 3 herds of Ukrainian black-pied dairy breeds

\begin{tabular}{|c|c|c|c|c|c|c|}
\hline \multirow{3}{*}{ Alleles } & \multicolumn{6}{|c|}{ Frequency, \% } \\
\hline & \multicolumn{2}{|c|}{ herd $A, n=122$} & \multicolumn{2}{|c|}{ herd $B, n=82$} & \multicolumn{2}{|c|}{ herd C, $\mathrm{n}=89$} \\
\hline & $P_{a}{ }^{\mathrm{I}}$ & $P_{a}^{\text {II }}$ & $P_{a}{ }^{\mathrm{I}}$ & $P_{a}^{\mathrm{II}}$ & $P_{a}{ }^{\mathrm{I}}$ & $P_{a}^{\mathrm{II}}$ \\
\hline *01 & 1.23 & 2.46 & 4.88 & 9.76 & $9.55^{\mathrm{a}}$ & 19.1 \\
\hline *02 & 1.64 & 3.28 & - & - & 1.69 & 3.37 \\
\hline *03 & 4.92 & 9.84 & 7.32 & 13.4 & $7.3^{\mathrm{b}}$ & 14.6 \\
\hline *04 & 1.64 & 3.28 & - & - & 1.12 & 2.25 \\
\hline *05 & - & - & - & - & 0.56 & 1.12 \\
\hline *06 & - & - & 1.83 & 3.66 & 2.25 & 4.49 \\
\hline *07 & 4.92 & 9.02 & 4.88 & 8.54 & 3.37 & 5.62 \\
\hline *08 & 5.74 & 11.5 & $11.0^{\mathrm{a}}$ & 19.5 & 5.06 & 10.1 \\
\hline$* 10$ & 5.33 & 8.20 & - & - & 3.37 & 6.74 \\
\hline *11 & 1.64 & 3.28 & 6.71 & 13.4 & - & - \\
\hline *12 & 2.46 & 4.92 & 2.44 & 4.88 & 1.69 & 3.37 \\
\hline$* 13$ & 3.28 & 6.56 & 2.44 & 4.88 & 2.25 & 4.49 \\
\hline *14 & 0.82 & 1.64 & 0.61 & 1.22 & 2.25 & 4.49 \\
\hline$* 15$ & 1.64 & 3.28 & 0.61 & 1.22 & 0.56 & 1.12 \\
\hline$* 16$ & 5.74 & 11.5 & $9.15^{\mathrm{b}}$ & 18.3 & $7.87^{\mathrm{b}}$ & 14.6 \\
\hline *18 & 1.64 & 3.28 & 1.83 & 3.66 & 2.81 & 5.62 \\
\hline *19 & 0.82 & 1.64 & - & - & - & - \\
\hline *20 & 0.82 & 1.64 & - & - & - & - \\
\hline *21 & 2.05 & 4.1 & 1.22 & 2.44 & 1.69 & 3.37 \\
\hline *22 & $7.38^{\mathrm{b}}$ & 11.5 & $12.2^{\mathrm{a}}$ & 21.9 & $11.2^{\mathrm{a}}$ & 21.3 \\
\hline *23 & 4.92 & 9.84 & 5.49 & 11.0 & $7.3^{\mathrm{b}}$ & 14.6 \\
\hline *24 & $18.0^{\mathrm{a}}$ & 34.4 & 6.71 & 11.0 & $8.43^{\mathrm{b}}$ & 15.7 \\
\hline * 25 & 0.41 & 0.82 & - & - & 1.12 & 2.25 \\
\hline *26 & 2.46 & 4.92 & 1.22 & 2.44 & 2.25 & 4.49 \\
\hline *28 & $7.38^{\mathrm{b}}$ & 14.8 & $8.54^{\mathrm{b}}$ & 17.1 & 6.74 & 13.5 \\
\hline *29 & - & - & - & - & 1.12 & 2.25 \\
\hline *31 & 0.82 & 1.64 & - & - & - & - \\
\hline *32 & 2.05 & 4.1 & 1.22 & 2.44 & 1.12 & 2.25 \\
\hline *35 & - & - & 1.83 & 3.66 & - & - \\
\hline *36 & 2.87 & 5.74 & 1.22 & 2.44 & 2.81 & 5.62 \\
\hline *37 & 3.28 & 6.56 & 0.61 & 1.22 & 2.81 & 5.62 \\
\hline *39 & - & - & 1.22 & 2.44 & - & - \\
\hline *41 & 0.82 & 1.64 & - & - & 1.12 & 2.25 \\
\hline *42 & 0.82 & 1.64 & - & - & 0.56 & 1.12 \\
\hline *45 & - & - & 3.66 & 7.32 & - & - \\
\hline *48 & 1.64 & 3.28 & - & - & - & - \\
\hline *51 & 0.82 & 1.64 & 1.22 & 2.44 & - & - \\
\hline Total & 100 & - & 100 & - & 100 & - \\
\hline
\end{tabular}

Note: Pa Calculation on total quantity of alleles; Pa II Calculation on quantity of alleles in genotypes of animals; a $\mathrm{P}<0.001 ; \mathrm{b} \mathrm{P}<0.05$

The observed non-uniform distribution is significant, which was proved by a test according to Shapiro-Wilk statistics and KolmogorovSmirnov statistics with Lilliefors' significance: herd A $\left(\Sigma \chi^{2}=108.8\right.$ at $\mathrm{dF}=30$ and $\mathrm{P}>0.001 ; \mathrm{SW}=0.686 ; \mathrm{KS}=0.209)$, herd $\mathrm{B}\left(\Sigma \chi^{2}=73.1\right.$ at $\mathrm{dF}=24$ and $\mathrm{P}>0.001 ; \mathrm{SW}=0.851 ; \mathrm{KS}=0.233)$, herd $\mathrm{C}\left(\Sigma \chi^{2}=70.9\right.$ at $\mathrm{dF}=24$ and $\mathrm{P}>0.001 ; \mathrm{SW}=0.832 ; \mathrm{KS}=0.241$ ).

Any allele found in the DNA structure needs to be considered as a unit of genetic information, which can be used as a DNA-marker. The number of alleles per locus and their frequency ranges is a strictly population characteristic, whereas every animal in a genotype obtains only two of them. Therefore, one should pay attention to those alleles which appear in the populations most frequently and have significant deviation in the distribution compared to the normal, that is for those for which the values of Pierson's chi-squared test are higher than the critical $\left(\chi^{2}>3.84\right.$ at $\mathrm{dF}=1$ and $\left.\mathrm{P}>0.05\right)$. In the herd $\mathrm{A}$, three such alleles were found $(* 22, * 24$ and $* 28)$, in the herd B - four $(* 08, * 16, * 22 i * 28)$ and in the herd C - six $(* 01, * 03, * 16, * 22, * 23$ and $* 24)$. Only one allele BoLA-DRB3.2*22 in the three subpopulations had significant deviation from the uniform distribution, providing reasons to analyze it as "significant" for the breed in general. In total, of the 293 samples it was found 58 times, though the most common allele in the studies was allele *24 (70 occurrences).

In selection of herd A, six alleles with frequency of over $5 \%$ were found: $* 08, * 10, * 16, * 22, * 24, * 28$. Their consolidation equaled $49.6 \%$.
The most often found allele was allele *24 with frequency of $18 \%$. It was also most often found in the genotype of cows. Its carriers were 42 animals (34.4\%). Among 82 samples of blood of herd B, eight alleles with frequency over $5 \%$ were found: $* 03, * 08, * 16, * 22, * 23, * 24, * 28$, which in total equals $67.1 \%$. The most abundant was the allele *22 (12.2\%) which was found in 18 cows $(21.9 \%)$. In the herd $\mathrm{C}$, we found 8 alleles with frequency over $5 \%: * 01,{ }^{*} 03, * 08,{ }^{*} 16, * 22, * 23, * 24$ and $* 28$, which in total occupy $63.5 \%$ of the allele pool. The most common allele was BoLA-DRB3.2*22 (11.2\%), carried by 19 animals (21.3\%). In total, for three subpopulations, seven alleles were informative $(55.8 \%)$. The highest result was obtained for allele BoLA-DRB3.2*24, which was found in 65 cows $(22.2 \%)$. In determining alleles which characterize the selection, one should take into account that some of them are found in homozygous genotype (Table 2). In total, 8 variants of homozygotes were found in the population. The genotypes most often found (by 5 times) were genotypes $* 10 / * 10, * 22 / * 22 \mathrm{i} * 24 / * 24(1.71 \%)$.

Table 2

The number of homozygous animals for BoLA-DRB3.2 genotype

\begin{tabular}{rccc}
\hline Homozygotes & Herd A & Herd B & Herd C \\
\hline DRB3. $2 * 3$ & - & 1 & - \\
DRB3. $2 * 07$ & 1 & 1 & - \\
DRB3. $2 * 08$ & - & - & 1 \\
DRB3. $2 * 10$ & 3 & 2 & - \\
DRB3. $2 * 22$ & 4 & - & 1 \\
DRB3. $2 * 23$ & - & 2 & - \\
DRB33. $2 * 24$ & 2 & 2 & 1 \\
DRB3. $2 * 28$ & - & 1 & - \\
Total & 10 & 9 & 4 \\
\hline
\end{tabular}

In cases of heterozygous genotype, both alleles carry different genetic information. The presence of homozygotes decreases to a certain extent the informatively of the alleles compared to heterozygous genotypes. If an allele is present in a homozygous genotype, then the number of animals in which it is found decreases by the number of homozygous variants. For example, in herd A, alleles $* 22$ and $* 28$ were 18 times each, which equaled by $7.4 \%$. However, allele $* 22$ was found four times in a homozygous genotype. Therefore, its carriers were only 14 cows, which equaled $11.5 \%$, and allele $* 28$ which was observed only in heterozygous genotype - was found in 18 animals, which equaled $14.8 \%$ (Table 1). Informative value of allele polymorphism decreases as the homozygosity of the herd grows.

A broad range of alleles of the BoLA-DRB3 gene causes a high number of genotypes and their uniform distribution. In herd $\mathrm{A}$, we found 75 (mean frequency 1.63), in herd B - 65 (1.26) and in herd C 67 (1.33) genotypes. The most abundant of them are demonstrated in Table 3. In total, in 293 cows we found 155 (1.89) genotypes. Among them, the most frequent -7 times $(2.4 \%)$ each - genotypes determined were BoLA-DRB3. $2 * 22 / * 24$ and BoLA-DRB3. $2 * 24 / 24$.

Apart from allele frequencies in a single locus, which indicate genetic variability of the population, an important indicator which characterizes the structure of a herd is heterozygosity. The frequency of heterozygotes is a significant parameter, for each heterozygous individual has different alleles, thus indicating the presence of variability. The values of expected and observed heterozygosity are presented in Table 3. The level of expected heterozygosity in the studied herds is quite high and uniform. The deviations between the border values did not exceed $0.8 \%$. In general, the observed and expected heterozygosity of the population equaled 0.922 and 0.942 respectively, which indicates insignificant excess of homozygotes.

Decrease in heterozygosity was determined for herd A and herd B. The disadvantage of heterozygotes was evaluated by the value of individual index of Wright's fixation index (Fig. 1) for them equaled correspondingly $\mathrm{F}_{\mathrm{IS}(\mathrm{A})}=0.016\left(\chi^{2}=0.03 ; \mathrm{P}>0.05\right)$ and $\mathrm{F}_{\mathrm{IS}(\mathrm{B})}=0.044$ $\left(\chi^{2}=0.076 ; \mathrm{P}>0.05\right)$. In herd $\mathrm{C}$, an excess of heterozygotes was determined: $\mathrm{F}_{\mathrm{IS}(\mathrm{C})}=-0.017\left(\chi^{2}=0.026 ; \mathrm{P}>0.05\right)$. In all subpopulations, the deviations from HWE (Hardy-Weinberg equilibrium) were not significant. Therefore, the presumption about the impact of inbreeding or outbreeding on the determined deviation from the normal distribution can be false, though completely ignoring the impact of selective pressure on the determined changes in the heterozygosity would be a rash decision. 
Subpopulational coefficient $\mathrm{F}_{\mathrm{ST}}$ indicates decrease in heterozygosity due to limitations of flow of genes and genetic drifts between the populations. It changes from the null value (panmixia, levels of frequencies of alleles in populations, no divergence) to 1 (complete isolation, high differentiation, populations observed with different particular alleles, pure lines). The following values of subpopulational index of fixation were obtained: $\mathrm{F}_{\mathrm{ST}(\mathrm{A})}=0.009\left(\chi^{2}=65.9 ; \mathrm{P}<0.01\right), \mathrm{F}_{\mathrm{ST}(\mathrm{B})}=0.012\left(\chi^{2}=\right.$ 47.2; $\mathrm{P}<0.05)$ and $\mathrm{F}_{\mathrm{ST}(\mathrm{C})}=0.003\left(\chi^{2}=14.4 ; \mathrm{P}>0.05\right)$. Values were low and significantly different from the average value for cattle $\left(\mathrm{F}_{\mathrm{ST}}=\right.$ $0.078, \mathrm{n}=29$ ) (Kuznecov, 2014). Comparing the obtained values of $\mathrm{F}$ statistics with levels of gradations suggested by Wright (divergence 0 0.05 low, $0.06-0.15$ mean, $0.16-0.25$ high and $\mathrm{F}_{\mathrm{ST}}>0.25$ significant) (Wright, 1978), one should assess the extent of the reduction of heterozygosity and divergence as very low, which indicates an insignificant impact of combined impact of gene drift, gene flow, mutations and selection on the genetic variability between the populations.

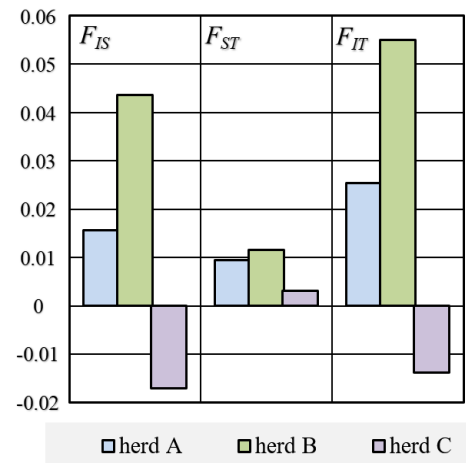

Fig. 1. Wright's F-statistics for experimental herds: individual ( $\left.\mathrm{F}_{\mathrm{IS}}\right)$, subpopulational $\left(\mathrm{F}_{\mathrm{ST}}\right)$ and populational $\left(\mathrm{F}_{\mathrm{IT}}\right)$

Population level of genetic structure according to Wright's statistics is close to the individual fixation index. During the assessment of a complex of subpopulations, its significance increases as their number rises. Also, the informativity of $F_{I T}$ depends on the number of loci used for the analysis of the genetic structure. In our study, we had only one locus and three herds. Therefore, $\mathrm{F}_{\mathrm{IT}}$ statistics is interpreted as a coefficient of inbreeding of individuals according to the general selection. If $\mathrm{F}_{\mathrm{IT}}>0$, then a population has deficiency, and at $\mathrm{F}_{\mathrm{IT}}<0$ - there is an excess of heterozygotes. The value of the population index completely correlates with the values of individual statistics and does not require more precise explanation.

Diversity of any system is conditioned by two components:

- variability of elements of the system characterized by their total number;

- non-uniformity of distribution of the elements, which determines "significance" of the elements.

Taking this into account, we calculated three parameters which determine the genetic diversity of the studied subpopulations of the Ukrainian black-pied dairy breed. Table 3 demonstrates the calculated values of effective allele number, efficiency index and Shannon's information index.

Total number of alleles found in the selection indicates only the number of determined features. But the higher the number of alleles available for assessment, the higher the level of informatively. Effective number of alleles is a function from a number of alleles per locus and uniformity of distribution of their frequencies. This indicator assesses the extent, reversible homozygosity, and is the number of alleles at the equal frequency of which, the heterozygosity in a population will equal the factual. Basically, this is a minimum number of alleles which can provide an existing level of heterozygosity. The higher the non-uniformity of distribution of particles, the lower the value $\mathrm{N}_{\mathrm{e}}$.

In spite of the fact that the total number of the determined alleles in the selections is different, it is logical that during the analysis, one uses the efficiency index $\mathrm{A}_{\mathrm{e}} / \mathrm{N}_{\mathrm{a}}$ which demonstrates the share of efficient alleles among all alleles found in a population. The higher is the value of the index, the higher is the genetic diversity. At equal levels of expected heterozygosity, the informatively is higher at a lower number of distin- guished alleles. This is proved by the calculations of efficiency index values. Its minimum value of 0.48 was determined for herd $\mathrm{A}$, where the number of alleles found was the highest. Obviously, the size of allele constant rate does not always reflect the genetic diversity of a population accurately.

Table 3

Genetic structure of the subpopulations

of Ukrainian black-pied dairy breeds for the BoLA-DRB3 gene

\begin{tabular}{|c|c|c|c|c|}
\hline \multicolumn{2}{|l|}{ Indication } & Herd A & Herd B & Herd C \\
\hline \multicolumn{2}{|l|}{ Number of cows } & 122 & 82 & 89 \\
\hline \multirow{2}{*}{\multicolumn{2}{|c|}{$\begin{array}{l}\text { Number of observed } \\
\text { homozygotes expected }\end{array}$}} & 10 & 9 & 4 \\
\hline & & 8.2 & 5.68 & 5.43 \\
\hline \multirow{2}{*}{\multicolumn{2}{|c|}{$\begin{array}{l}\text { Number of observed } \\
\text { heterozygotes expected }\end{array}$}} & 112 & 74 & 85 \\
\hline & & 113.8 & 76.3 & 83.6 \\
\hline \multirow{3}{*}{ Alleles } & per locus, $N_{a}$ & 31 & 25 & 28 \\
\hline & $\begin{array}{l}\text { No. } \\
(\%)\end{array}$ & $\begin{array}{c}* 24(18.0), * 22 \\
\text { and } * 28(7.38 \\
\text { each }), * 08 \text { and } \\
* 16(5.74 \text { each }) \\
* 10(5.33)\end{array}$ & $\begin{array}{c}22(12.2), * 08 \\
(11.0), * 16(9.15), \\
* 28(8.54), * 11 \\
\text { and *24(6.71 } \\
\text { each), *23(5.49) }\end{array}$ & $\begin{array}{c}* 22(11.2), * 01 \\
(9.55), * 24(8.43), \\
* 16(7 ., 87), * 03 \\
\text { and *23 (7.3 } \\
\text { each), *28 (6.74), } \\
* 08(5.06)\end{array}$ \\
\hline & $\sum, \%$ & 49.6 & 67.1 & 63.5 \\
\hline \multirow[b]{2}{*}{ Genotypes } & tal & 75 & 65 & 67 \\
\hline & $\operatorname{ng}(\%)$ & $\begin{array}{c}* 02 / * 28 \\
* 22 / * 22 \\
* 16 / * 24 \\
(3.28 \text { each })\end{array}$ & $\begin{array}{c}* 01 / * 22, * 03 / * 22, \\
* 07 / 08, * 08 / 08, \\
* 08 / * 16, * 08 / * 23, \\
* 08 / * 28, * 11 / * 16, \\
* 11 / * 24, * 11 / * 24, \\
* 22 * 22, * 22 * 28, \\
* 22 * 45, * 23 / * 28, \\
* 24 / * 24 \text { and } \\
* 24 / * 35(2.44 \\
\text { each) }\end{array}$ & $\begin{array}{c}* 01 / * 24 \text { and } \\
* 22 / * 24 \\
(4.49 \text { each }) \\
* 01 / * 03, \\
* 01 / * 28, \\
* 03 / * 37, \\
* 16 / * 23 \\
(3.37 \text { each })\end{array}$ \\
\hline Hetero- & & 0.918 & 0.89 & 0.955 \\
\hline zygosity & & 0.933 & 0.931 & 0.939 \\
\hline Effective allele numb & $r, A_{e}$ & 14.9 & 14.5 & 16.4 \\
\hline Efficiency index, $A_{e} / \Lambda$ & & 0.48 & 0.58 & 0.59 \\
\hline $\begin{array}{l}\text { Shannon's informatio } \\
\text { index, } I\end{array}$ & & 3.05 & 2.87 & 3.01 \\
\hline
\end{tabular}

Shannon's information index is used for characterizing the variability of allele range according to the BoLA-DRB3 gene (Panei et al., 2009). It demonstrates the extent of chaotic pattern of distribution of the elements of the system. Higher values of the indices correspond to the maximum chaotic extent of the distribution. In the case of opposite, the system is organized, i.e. the allele range is less diverse. In our study, we found quite high values of Shannon's information index. Its mean value for three herds is $\mathrm{I}=3.13$, which is one of the highest values among all breeds of cattle (Fig. 5). However, Shannon's information index does not always correlate with parameters of expected heterozygosity, effective allele number and efficiency index. In our opinion, this occurs because the diversity in the index is explained as the amount of information for one component. It is sensitive to the changes of frequencies of "significant" alleles and better characterizes the aligning of the diversity components (Whittaker, 1972).

The determined frequencies of alleles allowed us to identify the phylogenetic relations between the studied subpopulations according to the BoLA-DRB3 gene. For their determination, we used the method of determining evolutionary distance, developed on comparison of nucleotide sequences of homologous genes. Having determined frequencies of alleles of a particular gene for two populations, genetic distance indicates factual assessment of the mean value of changes of alleles in each locus, which occurred over the period of their separate evolution, expressed numerically. Through gradual change of frequencies (Nei, 1972), we calculated the genetic similarity and standard genetic distances (Table 4) and developed a dendrogram (Fig. 2).

During development of the dendrogram, we used UPGMA unweighted pair-group method using the centroid average. During the selection, we preferred a method using which the cogenetic coefficient of correlation had the highest value at a high level of significance (cogenetic correlation is the extent of how exactly the dendrogram maintains 
pair distances between the initial non-modeling points of data).

Table 4

Genetic distance and similarity between three herds of the Ukrainian black-pied dairy breed

\begin{tabular}{|c|c|c|c|}
\hline Herd & $\mathrm{A}$ & B & $\mathrm{C}$ \\
\hline$\overline{\mathrm{A}}$ & 0.000 & 0.771 & 0.828 \\
\hline B & 0.260 & 0.000 & 0.872 \\
\hline $\mathrm{C}$ & 0.189 & 0.137 & 0.000 \\
\hline
\end{tabular}

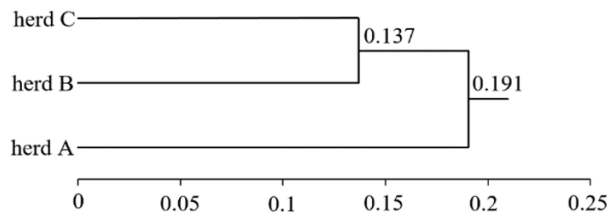

Fig. 2. UPGMA dendrogram based on Nei's DA genetic distance for three herds of Ukrainian black-pied dairy breed (Cophenetic Correlation: $\mathrm{R}=-0.828 ; \mathrm{dF}=1 ; \mathrm{P}=0.379 ;$ distance matrix; cluster method $=$ centroid $)$

The cows of herds $\mathrm{B}$ and $\mathrm{C}$ turned out to have a higher genetic affinity according to the BoLA-DRB3 gene. Genetic affinity between them was the highest $(0.872)$, which conditioned their unification into one cluster at the level of internal band $\mathrm{D}=0.137$. Such situation completely coincides with geographic and historical development of these subpopulations. The farms which keep the cows from these herds are geographically located near one another, making the genetic divergence minimum and logically conditioning unifications of them into one cluster.

\section{Discussion}

We analyzed the genetic diversity of three herds of the Ukrainian black-pied dairy breed at the level of polymorphism of alleles of the BoLA-DRB3 gene, an important gene of immunity. This is the most widespread cattle breed in Ukraine. Its population is estimated to be over 960 thousand animals, which is $3 / 8$ of the dairy cattle in the country (Gladiy et al., 2015). In livestock breeding farms, around 62 thousand animals $(4.6 \%)$ are kept.

The breed was created on the basis of crossbreeding of local blackpied animals of Dutch origin with Holstein Canadian and American selection. During creation and formation of the population mass of the black-spotted breed, offspring of Dutch, Estonian, Lithuanian blackpied animals from Moscow and other oblasts were used. Therefore, the current population of black-pied cattle in the farms of Ukraine is diverse in its genealogical structure and is not aligned by type (Kostenko et al., 2010; Piddubna, 2014).

\section{Table 5}

Indicators calculated from the frequencies of the BoLA-DRB3 gene for different populations of cattle: expected $\left(\mathrm{H}_{\mathrm{e}}\right)$ and observed $\left(\mathrm{H}_{\mathrm{o}}\right)$ heterozygosity, inbreeding coefficient $\left(\mathrm{F}_{\mathrm{IS}}\right)$, effective allele number $\left(\mathrm{A}_{\mathrm{e}}\right)$, efficiency index $\left(\mathrm{A}_{\mathrm{e}} / \mathrm{N}_{\mathrm{a}}\right)$ and Shannon's information index $(\mathrm{I})$

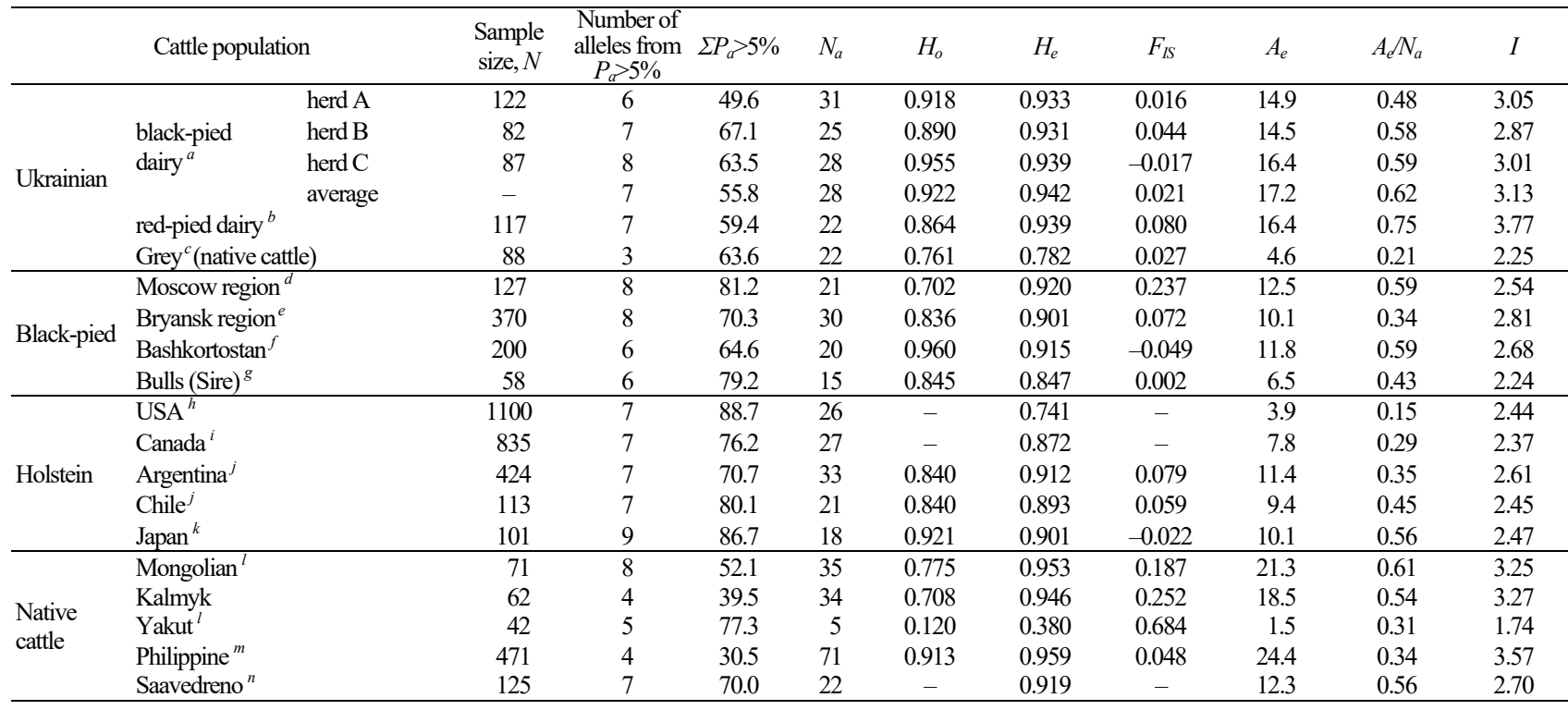

Note: ${ }^{\text {a }}$ present work; ${ }^{\mathrm{b}}$ Suprovych (2015); ${ }^{\mathrm{c}}$ Suprovych et al. $(2017 \mathrm{a}) ;{ }^{\mathrm{d}}$ Udina et al. $(2003) ;{ }^{\mathrm{e}}$ Smaznova et al. $(2010) ;{ }^{\mathrm{f}}$ Sharifullina \& Ahatova $(2004) ;{ }^{\mathrm{g}}$ Nam et al. (2014); ${ }^{\mathrm{h}}$ Dietz et al. (1997); ${ }^{\mathrm{i}}$ Sharif et al. (1998); ${ }^{\mathrm{j}}$ Takeshima et al. (2015a); ${ }^{\mathrm{k}}$ Takeshima et al. (2003); ${ }^{\mathrm{l}}$ Ruzina et al. (2010); ${ }^{\mathrm{m}}$ Takeshima et al. (2014); ${ }^{\mathrm{n}}$ Ripoli et al. (2004)

To evaluate the extent of the diversity of genes and evolutionary forces which formed it (selection, inbreeding, flow of genes, genetic drift, structure of population, etc.), we calculated the following parameters: expected $\left(\mathrm{H}_{\mathrm{e}}\right)$ and observed $\left(\mathrm{H}_{\mathrm{o}}\right)$ heterozygosity, $\mathrm{H}_{\mathrm{WE}}$, as estimated by the inbreeding coefficient $\left(\mathrm{F}_{\mathrm{IS}}\right)$, effective allele number $\left(\mathrm{A}_{\mathrm{e}}\right)$, efficiency index $A_{e} / N_{a}$ and Shannon's information index (I) for different populations (Table 5). Genetic diversity is a distinctive feature of the breed. This thesis is proved also by the fact that in these studies of subpopulations, 25 to 31 alleles were found. BoLA-DRB3 polymorphisms have been studied at the population level in most than 30 cattle breeds, including Jersey, Holstein, Black Pied, Ayrshire, Argentinian and Brazilian Creoles, Japanese Shorthorn, Japanese Black, Hanwoo, Nelore, Brazilian dairy Gir, Ongole, Martinique Brahman, and native breeds from East Asia and Latin America, which showed significant differences in the degree of polymorphism (Takeshima et al., 2014). According to our assessments of the data for 29 populations, the mean parameter equals 23.6 alleles of BoLA-DRB3 per locus. As expected, the high number of alleles $\left(\mathrm{N}_{\mathrm{a}} \geq 25\right)$ which was observed in the subpopulations conditions extremely high diversity.

Important for evaluating the diversity is the consolidation of alleles, to which belong those with frequency of occurrence of over 5\%. Many studies have established that the total of the frequencies of 6-7 alleles is over $65-70 \%$ of the allele pool. This indicates accumulation of single alleles, and elimination of others. Comparison of the results of our study with allele range and profile of gene frequencies determined for other breeds of cattle revealed the following. First, the breeds studied earlier had cumulative frequency of alleles $\left(\mathrm{P}_{\mathrm{a}}>0.05\right)$ ranging from $64.6 \%$ to $88.7 \%$, whereas for the three studied herds the range was $49.6 \%$ to $67.1 \%$ (we took into account only the breeds which were affinitive according to the origin - black-pied and Holstein). Secondly, the alleles found, and also the content of the alleles with highest frequencies insignificantly differ between the breeds. In general, for the three subpopulations, seven alleles were informative (\%): *03 (6.3), *08 (7.0), *16 (7.3), *22 (9.9), *23 (5.8), *24 (11.9) and *28 (7.5). By com- 
parison, 1100 Holstein cows from the USA (Dietz et al., 1997) and 835 cows from Canada (Sharif et al., 1998) were found to have seven consolidating alleles each, respectively for the USA $-* 22$ and $* 24$ (14.3), *08 (14.1), *16 (10.0), *23 (9.1), *11 (8.5) and *07 (5.3); Canada - *08 (20.1), *24 (19.2), *11 (14.9), *22 (13.7), *16 (9.2), *23 (6.4) and *03 (5.2). Among black-pied breeds, a similar situation was observed. For 4 herds in Briansk oblast (Smaznova et al., 2010), 8 alleles were found $\left(\mathrm{P}_{\mathrm{a}}>0.05\right)-* 24(12.6), * 11(10.8), * 23(9.5), * 08(9.3)$, $* 22(8.8), * 16(7.0), * 07$ (6.9) and *10 (5.4). Most of the abovementioned alleles occurred in the populations of black-pied cattle in Moscow oblast (Udina et al., 2003) - *22 (18.1), *24 (15.4), *11 (10.2), *16 (9.7), *18 (9.4), *23 (7.1), *08 (5.8) and *27 (5.5). Domination of 6-8 alleles of the BoLA-DRB3 gene with frequency of over 5\% is typical for most populations.

The cumulative effect was accompanied by impoverishment of the allele diversity of the population. A typical example is consolidation of identical alleles of BoLA-DRB3 in Holstein breeds. The effective population size of Holsteins, whose total population is several million, has been estimated at a few hundred or thousand (Qanbari et al., 2010). Genealogical analysis of the pedigree of this breed in all countries ends up with 20 bull-founders. Under the influence of such factors as migration of genes, selection, inbreeding, a secret genetic load of populations is able to rapidly change the frequency of alleles, and allele pools of breeds which were different at first become more and more similar and genetically uniform over time (Jernst et al., 2007). As a result of long term influence of these factors, an impoverishment of genetic diversity takes place, leading even to loss of insignificantly distributed alleles (Hedrick, 2010). Rare alleles do not make a great contribution to the general genetic variability, but can be important for the population during exceptional or periodic events, such as extreme temperature conditions, occurrence of new parasites or pathogens, and can provide a unique response to future evolutionary changes (Groom et al., 2006).

Cumulative effect conditions decrease of parameters of allele diversity of Holstein breeds and the herds affinitive to them. In populations of Holstein cows of USA and Canada (Table 5), 26 and 27 BoLADRB3 alleles were found respectively. This is quite high value. But the significant level of allele consolidation conditioned insignificant heterozygosity, and as a result - the lowest parameters of diversity of commercial breeds. Holstein cattle (USA) were observed to have the lowest number of effective alleles $\left(A_{e}=3.86\right)$, minimum values of effectiveness index $\left(\mathrm{A}_{\mathrm{e}} / \mathrm{N}_{\mathrm{a}}=0.15\right)$ and Shannon's information index $(\mathrm{I}=2.44)$. These parameters were slightly higher in Holstein cattle in Argentina, Chile and Japan, but not higher than these parameters for black-pied and most native cattle (except Yakutian). Selection load occurring at constant cross-breeding of the maternal breed only with Holstein bulls eliminates its genetic diversity.

The information obtained in earlier studies of herd A also deserves attention (Suprovych et al., 2017c). For improving milk productivity on a farm, selective procedures are applied for increasing the purebredness of the Holstein breed. The maternal population is constantly inseminated with sperm of pedigree bulls. As a result, the share of purebredness of the Holstein breed in herd A reached $93.8 \%$, causing changes in the allele pool in relation to the BoLA-DRB3 gene. Over 5 years of intense Holsteinisation (first study was conducted in 2009-2010, the second in 2005), there was observed an enlargement of the allele range from 28 to 32 , and consolidation of alleles typical for the Holstein breed. The total of 8 alleles most commonly distributed for it $(* 03, * 07, * 08$, $* 11, * 16, * 22, * 23, * 24)$ increased by $6.2 \%$. In 2010 , the consolidation of alleles related to high dairy productivity equaled $31.8 \%$, and that related to low equalled $11.1 \%$, and in 2015 it equalled 37.3 and $12.7 \%$ respectively. Genetic affinity determined according Nei between purebred Holstein animals and the herd of Ukrainian black-pied dairy breed in 2015 increased from 0.743 to 0.828 units, whereas genetic distance between the herds of the first and the second studies increased by 0.081 units. The number of effective alleles decreased from 16.3 to 14.9 , and the effectiveness index decreased from 0.58 to 0.48 .

As expected, a large number of alleles with significant frequencies of gene alleles condition very high values of heterozygosity. This was proved in our research, where the level of heterozygosity was $\mathrm{H}_{0}>0.89$ and $\mathrm{H}_{\mathrm{e}}>0.93$. All breeds, except Yakutian, were observed to have expected heterozygosity within the values from 0.741 to 0.959 (Table 5).

Such a result for the BoLA-DRB3 gene is expected for one of the hypotheses which explain high level of polymorphism of MHC genes is super domination. Polymorphism of the MHC molecule determines the ability of different immune reactions. It was found that particular products had variability to provide T-cells with alien protein. Selection favouring heterozygotes leads to creation of a stable polymorphic balance conditioned by antigen-bonding functions of the molecules of the complex. Therefore, in populations affected by numerous pathogens, heterozygous individuals will have an advantage because they are able to bond with a large number of alien antigens (Hedrick et al., 1991). Evidence of the described processes is the fact that the polymorphism of immune response genes is supported by a certain form of balanced selection (Hughes \& Nei, 1989). Logically, in panmixia populations an excess of heterozygotes was found, while artificially created breeds had a deficiency.

Genetic characteristics of local (native) breeds have their own specific. Some of them have a complex origin. Accordingly, Phillipine cattle mostly derive from Chinese and Mexican cattle (Takeshima et al., 2014). The Saavedreno breed was obtained by cross breeding different populations of Creole cattle and are kept outdoors (without housing) all year and maintained under extensive stationary pastoral conditions with only a mineral supplement (Ripoli et al., 2004). Mongolian, Kalmyk, Yakut cattle are kept in the conditions of free pasture. Most local populations are limited in size and not affected by selectional load in the form of artificial selection.

The total of the described factors cause decrease of genetic diversity. Therefore, the $\mathrm{H}_{\mathrm{o}}=0.12$ and $\mathrm{H}_{\mathrm{e}}=0.38$ indicators of heterozygosity in the Yakutian breed were the lowest among the breeds (Table 5). The low population, geographic isolation, genetic drift and the founder effect condition the accumulation of one or two alleles of BoLA-DRB3 gene, as a result causing increase in heterozygosity $\left(\mathrm{F}_{\mathrm{IS}}=0.684\right)$, and the indicators of genetic diversity reaching minimum values among the studied breeds $\left(A_{e}=1.52, A_{e} / N_{a}=0.31, I=1.74\right)$. Accordingly, the Yakutian breed is characterized as the least diverse in terms of the BoLA-DRB3 gene. Clearly manifested inbreeding is accompanied by decrease in fertility, high level of barrenness and the necessity of multitime insemination. A similar situation can occur for Ukrainian grey cattle (Suprovych et al., 2017a), where the consolidation of the allele of BoLA-DRB3. $2 * 16$ was observed at the level of $43 \%$, though for the Kalmyk and Mongolian breeds the extent of heterozygosity was higher.

We obtained a deviation from $\mathrm{H}_{\mathrm{WE}}$, calculated according to the value of individual fixation index towards both sides from zero. According to $\mathrm{F}_{\mathrm{IS}}$ statistics, the majority of the populations, including the researched herds A and B, are characterized by deficiency of heterozygotes. Among the evaluated populations, only the Ukrainian blackpied dairy (herd C), Bashkortostan black-pied and Holsteinized Japan were observed to have excess of heterozygotes. The overdominance selection coefficient at MHC loci is quite low (probably less than 0.02) and could probably explain the absence of heterozygote excess in some breeds/populations (Mikko et al., 1999).

Among those that had significant dominance of homozygotes, there was only one commercial breed - black-pied from Moscow oblast $\left(F_{\text {IS }}=0.237\right)$ - and three local breeds, the special features of which were described above: Kalmyk, Mongolian and Yakutian. Despite the factors which decrease genetic diversity, Ukrainian grey cattle is characterized by an insignificant shift towards domination of homozygotes $\left(\mathrm{F}_{\mathrm{IS}}=\right.$ 0.027). In our opinion, absence of inbreeding in two farms, where this breed is kept, can be explained by correctly conducted selective work.

As was mentioned, the determined deviations for the three populations we studied were insignificant and did not undergo $\chi^{2}$ test. This relates to most other breeds. For accurate assessment of significance of deviation from $\mathrm{H}_{\mathrm{WE}}$, a number of authors (Miyasaka et al., 2011; Takeshima et al., 2015a) use Slatkin's exact test of neutrality. However, the results of this test quite rarely prove the significance of the obtained deviations and do not indicate the factors which condition the reduction of heterozygosity. According to the alleles of the BoLA-DRB3 gene, genetic affinity was calculated (Table 6). For convenience of comparison, 3 blocks were formed: * - Ukrainian black-pied dairy, ** - blackpied and $* * *-$ Holstein breeds. 
Table 6

Genetic similarity estimated through Nei between a pairs of populations at gene BoLA-DRB3 allele's frequencies (**-Ukrainian black-pied dairy (own research); ** - black-pied cattle; *** - Holsteins)

\begin{tabular}{|c|c|c|c|c|c|c|c|c|c|c|c|}
\hline Breed & *herd B & *herd C & $\begin{array}{l}\text { **Moscow } \\
\text { region }\end{array}$ & $\begin{array}{c}* * \text { Bryansk } \\
\text { region }\end{array}$ & $\begin{array}{c}\text { **Bashko- } \\
\text { rtostan }\end{array}$ & $\begin{array}{c}\text { **Bulls } \\
\text { (Sire) }\end{array}$ & ***USA & $* * *$ Canada & $\begin{array}{l}* * * \text { Argen- } \\
\text { tina }\end{array}$ & $* * *$ Chile & ***Japan \\
\hline *herd A & 0.771 & 0.828 & 0.759 & 0.832 & 0.817 & 0.85 & 0.763 & 0.807 & 0.853 & 0.911 & 0.738 \\
\hline *herd B & - & 0.872 & 0.794 & 0.828 & 0.804 & 0.745 & 0.825 & 0.873 & 0.819 & 0.794 & 0.848 \\
\hline *herd C & - & - & 0.732 & 0.738 & 0.813 & 0.763 & 0.662 & 0.759 & 0.776 & 0.821 & 0.722 \\
\hline **Moscow region & - & - & - & 0.858 & 0.912 & 0.864 & 0.846 & 0.901 & 0.916 & 0.716 & 0.847 \\
\hline **Bryansk region & - & - & - & - & 0.831 & 0.819 & 0.896 & 0.921 & 0.889 & 0.757 & 0.818 \\
\hline **Bashkortostan & - & - & - & - & - & 0.823 & 0.728 & 0.822 & 0.858 & 0.749 & 0.736 \\
\hline **Bulls (Sire) & - & - & - & - & - & - & 0.817 & 0.870 & 0.961 & 0.700 & 0.844 \\
\hline$* * *$ USA & - & - & - & - & - & - & - & 0.953 & 0.888 & 0.708 & 0.894 \\
\hline ***Canada & - & - & - & - & - & - & - & - & 0.944 & 0.758 & 0.930 \\
\hline ***Argentina & - & - & - & - & - & - & - & - & - & 0.723 & 0.894 \\
\hline$* * *$ Chile & - & - & - & - & - & - & - & - & - & - & 0.743 \\
\hline
\end{tabular}

Among the herds we studied, the highest genetic similarity $(0.872)$ was observed between herds $\mathrm{B}$ and $\mathrm{C}$, which correlates with the geographic and historical development of these subpopulations. High genetic affinity, as expected, was observed between the populations of Holstein animals except Chilean cattle. The most affinitive by BoLA-DRB3 gene (0.951) were the USA and Canada herds. High similarity was observed between populations of the black-pied breed.

Ukrainian black-pied dairy breed herds demonstrated a high level of affinity, both with black-pied and Holstein cattle. Mean values of genetic similarity between the studied herds on the one hand, and Holstein and black-pied populations on the other hand equaled 0.798 and 0.789 respectively. The high affinity obtained in comparison is completely expected because the black-pied cattle is the maternal breed and the Holstein breed was used as an improving breed in the creation the Ukrainian black-pied dairy breed. Also, it should be mentioned that over a long time, a large scale process of Holsteinization goes on, accompanied with saturation of allele pool of the breed with consolidating alleles of Holstein animals (Suprovych et al., 2017c).

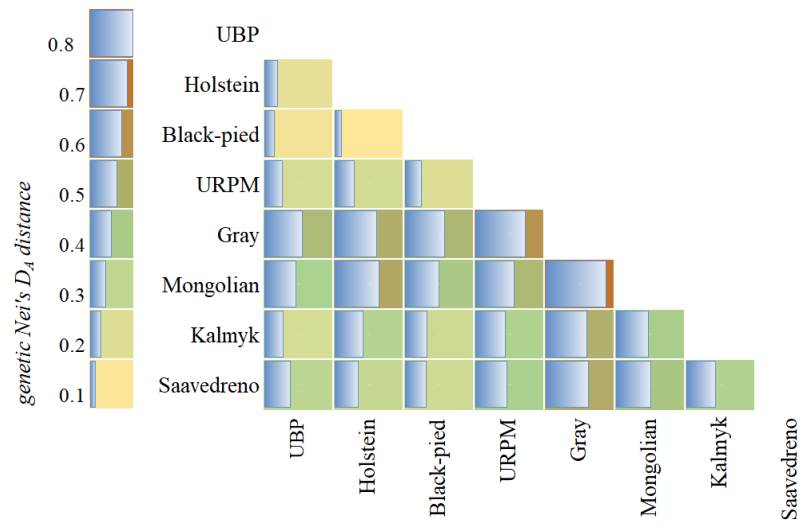

Fig. 3. Graphic matrix representation of genetic differentiation between breeds: UBP (Ukrainian black-pied dairy presented in this work average for 3 herds); URPM (Ukrainian red-pied dairy); Black-pied (average for four herds); Holstein (average for Holstein herds USA and Canada); the data for calculation taken from literature sources in notes Table 5; the DA values are coded with a colour code with the legend on the left side; the colours ranged from yellow to light red and correspond to the DA values

Between herd B and Holstein cattle, the highest values of genetic affinity were observed for USA cattle and Canadian cattle -0.825 and 0.873 respectively. These indicators completely coincide with peculiarities of selection work on farms, where the research was conducted. In herd B, insemination of maternal cattle used only sperm of Holstein bulls. In herds $\mathrm{A}$ and $\mathrm{C}$, some of the cows was inseminated with sperm of black-red bulls, which conditioned higher values of genetic similarity of these subpopulations with the maternal breed.

For evaluation of genetic differentiation of alleles between Ukrainian black-pied dairy and other breeds which were studied earlier using the method of PCR-RFLP, we conducted analysis on the basis of genetic distances (Fig. 3). Allele frequencies were used for generation of genetic distances DA according to Nei (Nei et al.,1983). The lowest value $(\mathrm{DA}=0.081)$ was determined between Holstein animals and black-pied cattle. The breed we studied occupies an intermediary position, for the value of genetic distances equaled: $\mathrm{DA}=0.164$ for Holstein cattle and DA $=0.125$ for black-pied cattle. The obtained results completely coincide with the data on genetic similarity between different populations of these breeds. A higher genetic divergence was observed between Ukrainian black-pied dairy and other breeds (DA > 0.200), which reaches maximum values in relation to native cattle.

\section{Conclusions}

We described the diversity of the BoLA-DRB3 gene of class 2 in three subpopulations of the Ukrainian black-pied dairy breed. The results demonstrated in our study emphasize the high extent of polymorphism of the studied herds. The determined distributions of frequencies and cumulative frequencies of alleles, values of expected heterozygosity, effective allele number, efficiency index and Shannon's information index compared to the similar parameters of other breeds of cattle indicate a high genetic diversity of the studied subpopulations. The breed is open, which is indicated by the high number of alleles of the gene and its genotypes. Genetic variability provides a substrate, from which adaptations develop, and is essential for constant evolutionary changes. The gene pool maintained in the breed is fundamental for its further development, because the genetic diversity of the initial material is the main resource for efficient and successful selective work. This study also proves the significance of the MHC region in animal live-stock farming and significantly enlarges our knowledge on the diversity and polymorphism in this locus for cattle reared in Ukraine.

\section{References}

Avise, J. (1994). Molecular markers, natural history and evolution. Champan and Hall. ITP International Thomson Pub. Comp. USA. Pp. 141-189.

Begon, M., Townsend, C. R., \& Harper, J. L. (2006). Ecology: From individuals to ecosystems. Blackwell Publishing Ltd, Oxford.

Behl, J. D., Verma, N. K., Tyagi, N., Mishra, P., Behl, R., \& Joshi, B. K. (2012). The major histocompatibility complex in bovines: A review. ISRN Veterinary Science, ID 872710.

Das, D. N., Sri Hari, V. G., Hatkar, D. N., Rengarajan, K., Saravanan, R., Suryanarayana, V. V., \& Murthy, L. K. (2012). Genetic diversity and population genetic analysis of bovine MHC class II DRB3.2 locus in three Bos indicus cattle breeds of Southern India. International Journal of Immunogenetics, 39(6), 508-519.

Dietz, A. B., Cohen, N. D., Timms, L., \& Kehrli, M. E. (1997). Bovine lymphocyte antigen class II alleles as risk factors for high somatic cell counts in milk of lactating dairy cows. Journal of Dairy Science, 80(2), 406-412.

Dobzhansky, T. (1970). Genetics of the evolutionary process. Columbia University Press, New York.

Gaevskij, N. A. (2002). Znakomstvo s jevoljucionnoj genetikoj [Acquaintance with evolutionary genetics]. Krasnojarsk (in Russian).

Gelhaus, A., Schnittger, L., Mehlitz, D., Horstmann, R. D., \& Meyer, C. G. (1995). Sequence and PCR-RFLP analysis of 14 novel BoLADRB3 alleles. Animal Genetics, 26(3), 147-153. 
Giovambattista, G., Ripoli, M. V., Peral-Garcia, P., \& Bouzat, J. L. (2001). Indigenous domestic breeds as reservoirs of genetic diversity: The Argentinean Creole cattle. Animal Genetics, 32, 240-247.

Gladiy, M. V., Bashhenko, M. I., Polupan, Y. P. (2018). Selekcijni, genetychni ta biotehnologichni metody udoskonalennja i zberezhennja genofondu porid sil's'kogospodars'kyh tvaryn [Breeding, genetic and biotechnological methods for improving and preserving the gene pool of breeds of farm animals]. IRGT im. M. V. Zubcja NAAN, Poltava (in Ukrainian).

Gladiy, M. V., Ruban, S. Y., Getya, A. A., \& Pryjma, S. V. (2015). Porody sils'kogospodars'kyh tvaryn Ukrai'ny. Istorija, stan, perspektyvy rozvytku [Breeds of farm animals in Ukraine. History, state, development prospects]. Breeding and Genetics of Animals, 49, 44-57 (in Ukrainian).

Gómez-Castro, S., Trujillo-Bravo, E., Carlos-Vicente, D., \& Agron, I. (2006). Polimorfismos de BoLA-DRB3 en el bovino sintético colombiano Lucerna y asociación con conteo de células somáticas y mastitis [BoLA-DRB3 polymorphism in Colombian synthetic cattle Lucerna and association with somaic cell counts and mastitis]. Revista Colombiana de Ciencias Pecuarias, 19(3), 270-279 (in Spanish).

Groom, M. J., Meffe, G. K., \& Carroll, C. R. (2006). Principles of conservation biology. 3rd Edition. Sinauer Associates, Sunderland.

Haikukutu, L., Itenge, T. O., Bosman, L., \& Visser, C. (2017). Genetic variability of the major histocompatibility complex (MHC) class II (DRB3) in South African and Namibian beef cattle breeds. Advances in Animal Biosciences, 8(s1), 19-21.

Hedrick, P. (2010). Genetic of populations. 4th Edition. Mass Jones and Bartlett Publishers, Sudbury.

Hedrick, P. W., Whittam, T. S., \& Parham, P. (1991). Heterozygosity at individual amino acid sites: Extremely high levels for HLA-A and -B genes. Proceedings of the National Academy of Sciences of the USA, 88(13), 5897-5901.

Hughes, A. L., \& Nei, M. (1989). Nucleotide substitution at major histocompatibility complex class II loci: Evidence for over dominant selection. Proceedings of the National Academy of Sciences of the USA, 86, 958-962.

Jernst, L. K., Zhigachev, A. I., \& Kudrjavcev, V. A. (2007). Monitoring geneticheskogo gruza $\mathrm{v}$ cherno-pestroj, golshtinskoj i ajrshirskoj porodah krupnogo rogatogo skota [Monitoring of the genetic cargo in the Black Pied, Holshtein and Ayrshire breeds of cattle]. Zootehnija, 3, 5-10 (in Russian).

Kostenko, V. I., Siratskyi, J. Z., Ruban, Y. D., Admin, Y. I., \& Shevchenko, M. I (2010). Tehnologija vyrobnyctva moloka i jalovychyny [Technology of milk and beef production]. Ahrarna Osvita, Kyiv (in Ukrainian)

Kovaljuk, N. V., Volchenko, A. E., Machulskaja, E. V., \& Satsuk, V. F. (2015). Lep gene allelic polymorphism in a subpopulation of Ayrshire cattle. Russian Journal of Genetics, 51(2), 214-217.

Kozyreva, N. G., Ivanova, L. A., Stepanova, T. V., \& Guljukin, M. I. (2014). Monitoring jepizooticheskoj situacii i primenenie molekuljarno-geneticheskoj diagnostiki v ozdorovitel'nyh meroprijatijah pri lejkoze krupnogo rogatogo skota [Application of DNA diagnostics in sanitation programs for eradication of Bovine Leucosis]. Dostizhenija Nauki i Tehniki APK, 1, 47-51 (in Russian).

Krajewska, M., Zabost, A., Welz, M., Lipiec, M., Orłowska, B., Anusz, K., Brewczyński, P., Augustynowicz-Kopeć, E., Szulowski, K., Bielecki, W., \& Weiner, M. (2015). Transmission of Mycobacterium caprae in a herd of European bison in the Bieszczady Mountains, Southern Poland. European Journal of Wildlife Research, 61(3), 429-433.

Kulberg, S., Heringstad, B., Guttersrud, O. A., \& Olsaker, I. (2007). Study on the association of BoLA-DRB3.2 alleles with clinical mastitis in Norwegian Red cows. Journal of Animal Breeding and Genetics, 124(4), 201-207.

Kuznecov, V. M. (2014). F-statistiki Rajta: Ocenka i interpretacija [Wright's Fstatistics: Estimation and interpretation]. Problemy Biologii Produktivnyh Zhivotnyh, 4, 80-104 (in Russian).

Maillard, J. C., Renard, C., Chardon, P., Chantal, I., \& Bensaid, A. (1999). Characterization of 18 new BoLA-DRB3 alleles. Animal Genetics, 30, 200-203.

Mikko, S., \& Andersson, L. (1995a). Low major histocompatibility complex class II diversity in European and North American moose. Proceedings of the National Academy of Sciences of the United States of America, 92(10), 4259-4263.

Mikko, S., \& Andersson, L. (1995b). Extensive MHC class II DRB3 diversity in African and European cattle. Immunogenetics, 42(5), 408-413.

Mikko, S., Roed, K., Schmutz, S., \& Andersson, L. (1999). Monomorphism and polymorphism at MHC DRB loci in domestic and wild ruminants. Immunological Reviews, 167(1), 169-178.

Miyasaka, T., Takeshima, S. N., Matsumoto, Y., Kobayashi, N., Matsuhashi, T., Miyazaki, Y., Tanabe, Y., Ishibashi, K., Sentsui, H., \& Aida, Y. (2011). The diversity of bovine MHC class II DRB3 and DQA1 alleles in different herds of Japanese Black and Holstein cattle in Japan. Gene, 472(1), 42-49.

Miyasaka, T., Takeshima, S. N., Sentsu, H., \& Aida, Y. (2012). Identification and diversity of bovine major histocompatibility complex class II haplotypes in Japanese black and Holstein cattle in Japan. Journal of Dairy Science, 95(1), $420-431$.
Mosafer, J., Heydarpour, M., Manshad, E., Russell, G., \& Sulimova, G. E. (2012). Distribution of BoLA-DRB3 allelic frequencies and identification of two new alleles in Iranian Buffalo breed. Scientific World Journal, 2012, 863024.

Nagylaki, T. (1998). Fixation indices in subdivided populations. Genetics, 148(3), 1325-1332.

Nam, I., Zayakin, V., Smaznova, I., Egiazaryan, A., Sulimova, G., Sheiko, I., \& Budevich, A. (2014). High genetic susceptibility to leukemia in breeding black pied and holstein cattle. Middle-East Journal of Scientific Research, 20(10), 1297-1301.

Nei, M. (1972). The genetic distance between populations. American Naturalist, 106(949), 283-292.

Nei, M., Tajima, F., \& Tateno, Y. (1983). Accuracy of estimated phylogenetic trees from molecular data. II. Gene frequency data. Journal of Molecular Evolution, 19(2), 153-170.

Oprzadek, J., Urtnowski, P., Sender, G., Pawlik, A., \& Lukaszewicz, M. (2012). Frequency of BoLA-DRB3 alleles in Polish Holstein-Friesian cattle. Animal Science Papers and Reports, 30(2), 91-101.

Panei, C. J., Suzuki, K., Echeverria, M. G., Serena, M. S., Metz, G. E., \& Gonzalez, E. T. (2009). Association of BoLA-DRB3.2 alleles with resistance and susceptibility to persistent lymphocytosis in BLV infected cattle in Argentina. International Journal of Dairy Science, 4, 123-128.

Peters, S. O., Hussain, T., Adenaike, A. S., Adeleke, M. A., De Donato, M., Hazzard, J., Babar, M. E., \& Imumorin, I. G. (2018). Genetic diversity of Bovine Major Histocompatibility Complex Class II DRB3 locus in cattle breeds from Asia compared to those from Africa and America. Journal of Genomics, 6, 88-97.

Piddubna, L. M. (2014). Golshtynizacija vidkrytoi' regional'noi' populjacii' chornorjaboi' molochnoi' hudoby ta perspektyvy i'i' podal'shogo udoskonalennja Holsteinization of open regional population of black-and-white cattle and prospects of its further improvement]. Animal Biology, 16(4), 121-132 (in Ukrainian).

Qanbari, S., Pimentel, E. C., Tetens, J., Thaller, G. E., Lichtner, P., Sharifi, A. R., \& Simianer, H. (2010). The pattern of linkage disequilibrium in German Holstein cattle. Animal Genetics, 41(4), 346-356.

Ranjbar, M. M., Ataei, S., Nikbakht, G., \& Golabdar, S. (2017). Analysis of variations, structures, and phylogenic characteristics of bovine leukocyte antigen DRB3 exon 2. Archives of Razi Institute, 72(3), 147-157.

Ripoli, M. V., Liron, J. P., De Luca, J. C., Rojas, F., Dulout, F. N., \& Giovambattista, G. (2004). Gene frequency distribution of the BoLA-DRB3 locus in Saavedreno Creole dairy cattle. Biochemical Genetics, 42(7/8), 231-240.

Ruzina, M. N., Shtyfurko, T. A., Mohammad Abadi, M. R., Gendzhieva, O. B. Cedev, C., \& Sulimova, G. E. (2010). Polimorfizm gena BoLA-DRB3 u krupnogo rogatogo skota mongol'skoj, kalmyckoj i jakutskoj porod [Polymorphism of the BoLA-DRB3 gene in the Mongolian, Kalmyk, and Yakut cattle breeds]. Russian Journal of Genetics, 46(4), 517-525 (in Russian).

Sharif, S., Mallard, B. A., Wilkie, B. N., Sargeant, J. M., Scott, H. M., Dekkers, J. C., \& Leslie, K. E. (1998). Associations of the bovine major histocompatibility complex DRB3 (BoLA-DRB3) alleles with occurrence of disease and milk somatic cell score in Canadian dairy cattle. Animal Genetics, 29, 185-193.

Sharifullina, N. M., \& Ahatova, I. A. (2004). Izuchenie DNK-polimorfizma gena BoLA-DRVZ v populjacii cherno-pestrogo skota pri pomoshhi polimeraznoj cepnoj reakcii [The study of the DNA polymorphism of the BoLA-DRB3 gene in a population of black-pied cattle by polymerase chain reaction]. Sovremennye problemy immunogeneza, teorii i praktiki bor'by s parazitarnymi infekcionnymi boleznjami sel'skohozjajstvennyh zhivotnyh. Moscow - Ufa. Pp. 321-323 (in Russian).

Singh, U., Deb, R., Alyethodi, R., Alex, R., Kumar, S., Chakraborty, S., Dhama K., \& Sharma, A. (2014). Molecular markers and their applications in cattle genetic research: A review. Biomarkers and Genomic Medicine, 6, 49-58.

Smaznova, I. A., Kozlov, A. L., Zajakin, V. V., \& Nam, I. J. (2010). Allel'nyj analiz gena BoLA-DRB3 v stadah krupnogo rogatogo skota Brjanskoj oblast [Allelic analysis of the BoLA-DRB3 gene in herds of cattle of Bryansk region]. Vestnik Brjanskogo Gosudarstvennogo Universiteta, 4, 227-232 (in Russian).

Stoltzfus, A. (2006). Mutationism and the dual causation of evolutionary change. Evolution and Development, 8(3), 304-317.

Sulimova, G. E. (2004). DNK-markery v geneticheskih issledovanijah: Tipy markerov, ih svojstva i oblasti primenenija [DNA markers in genetic research: Marker types, their properties and applications]. The success of modern biology, 124(3), 260-271 (in Russian)

Sulimova, G. E. (2006). DNK-markery v izuchenii genofonda porod krupnogo rogatogo skota [DNA markers in the study of gene pool of cattle breeds] Genofondy sel'skohozjajstvennyh zhivotnyh: Geneticheskie resursy zhivotnovodstva Rossii. Nauka, Moscow. Pp. 138-166 (in Russian).

Suprovych, T. (2015). Rozpodil aleliv gena BoLA-DRB3.2 u koriv ukrai'ns'koi' chervono-rjaboi' molochnoi' porody pry mastytah [Distribution allele of gene BoLA-DRB3.2 of Ukrainian red-pied dairy breed in connection with mastitis]. Stock Raising of Ukraine, 11, 15-19 (in Ukrainian). 
Suprovych, T. M., \& Suprovych, M. P. (2013). Polimorfizm aleliv gena BoLADRB3 na prykladi Ukrai'ns'kyh chorno-rjaboi' ta chervono-rjaboi' molochnyh porid [Allele polymorphism gene BoLA-DRB3 at the example of Ukrainian black-pied and red-pied dairy breeds]. Naukovyj visnyk NUBiP, 188(4), 144-152 (in Ukrainian).

Suprovych, T. M., Mokhnachova, N. B., Suprovych, M. P., \& Fursa, N. M. (2017a). Osoblyvosti rozpovsjudzhennja aleliv genu BoLA-DRB3 u siroi' ukrai'ns'koi' porody velykoi' rogatoi' hudoby [Features of the propagation of gene BoLA-DRB3 alleles in Gray cattle breeds]. Animal Breeding and Genetics, 54, 221-228 (in Ukrainian).

Suprovych, T., Suprovych, M., \& Kolinchuk, R. (2017c). Naslidky “golshtynizacii"' ukrai'ns'koi' chorno-rjaboi' molochnoi' porody za genom BoLADRB3.2 [Consequences of "Holsteinization" of Ukrainian black-pied dairy breed by gene BoLA-DRB3.2]. Animal Breeding and Genetics, 54, 146-156 (in Ukrainian).

Suprovych, T., Suprovych, M., Berezhansky, A., Kolinchuk, R., Chornyi, I., Ostafin, M., \& Bulski, K. (2017b). Polymorphism of the gene BoLA-DRB3 Ukrainian breeds of cattle. Scientific achievements in agricultural engineering, agronomy and veterinary medicine. Polish-Ukrainian Cooperation Scientific Monograph, 2(1), $44-64$.

Takeshima, S. N., Giovambattista, G., Okimoto, N., Matsumoto, Y., RogbergMuñoz, A., Acosta, T. J., Onuma, M., \& Aida, Y. (2015a). Characterization of bovine MHC class II DRB3 diversity in South American Holstein cattle populations. Tissue Antigens, 86(6), 419-430.

Takeshima, S. N., Miyasaka, T., Matsumoto, Y., Xue, G., Diaz, V., Rogberg-Munoz, A., Giovambattista, G., Ortiz, M., Oltra, J., Kanemaki, M., Onuma, M., \& Aida, Y. (2015b). Assessment of biodiversity in Chilean cattle using the distribution of major histocompatibility complex class II BoLA-DRB3 allele. Tissue Antigens, 85(1), 35-44.
Takeshima, S. N., Miyasaka, T., Polata, M., Kikuya, M., Matsumoto, Y., Mingala, C. N., Villanueva, M. A., Salces, A. J., Onuma, M., \& Aida, Y. (2014). The great diversity of major histocompatibility complex class II genes in Philippine native cattle. Meta Gene, 2, 176-190.

Takeshima, S., Nakai, Y., Ohta, M., \& Aida, Y. (2002). Characterization of DRB3 alleles in the MHC of Japanese Shorthorn Cattle by polymerase chain reaction-sequence-based typing. Journal of Dairy Science, 85(6), 1630-1632.

Takeshima, S., Saitou, N., Morita, M., Inoko, H., \& Aida, Y. (2003). The diversity of bovine MHC class II DRB3 genes in Japanese black, Japanese shorthorn, Jersey and Holstein cattle in Japan. Gene, 316, 111-118.

Teneva, A., \& Petrović, M. P. (2010). Application of molecular markers in livestock improvement. Biotechnology in Animal Husbandry, 26, 135-154.

Udina, I. G., Karamysheva, E. E., Turkova, S. O., Sulimova, G. E., \& Orlova, A. R. (2003). Genetic mechanisms of resistance and susceptibility to leukemia in Ayrshire and Black-pied cattle breeds determined by allelic distribution of gene BoLA-DRB3. Russian Journal of Genetics, 39(3), 306-317.

Van Eijk, M. J. T., Stewart-Haynes, J. A., \& Lewin, H. A. (1992). Extensive polymorphism of the BoLA-DRB3 gene distinguished by PCR-RFLP. Animal Genetics, 23(6), 483-496.

Werner, F. A., Durstewitz, G., Habermann, F. A., Thaller, G., Krämer, W., Kollers, S., Buitkamp, J., Georges, M., Brem, G., Mosner, J., \& Fries, R. (2004). Detection and characterization of SNPs used for identity control and parentage testing in major European dairy breeds. Animal Genetics, 35(1), 4449.

Whittaker, R. H. (1972). Evolution and measurement of species diversity. Taxon, 21(2/3), 213-251.

Workman, P. L., \& Niswander, J. D. (1970). Population studies on southwestern Indian tribes. II. Local genetic differentiation in the Papago. The American Journal of Human Genetics, 22(1), $24-49$.

Wright, S. (1978). Evolution and the genetics of populations. Volume 4: Variability Within and Among Natural Populations. University Chicago. 